\title{
Cisplatin chemotherapy (without erythropoietin) and risk of life-threatening thromboembolic events in carcinoma of the uterine cervix: the tip of the iceberg? A review of the literature Jon C Anders ${ }^{1}$, Perry W Grigsby ${ }^{2}$ and Anurag K Singh*3
}

\author{
Address: ${ }^{1}$ Radiation Oncology Associates, Albuquerque NM 87109, USA, ${ }^{2}$ Washington University School of Medicine, Department of Radiation \\ Oncology, St. Louis MO 63110, USA and ${ }^{3}$ National Cancer Institute, Radiation Oncology Branch, Bethesda MD 20892, USA \\ Email: Jon C Anders - andersj11@hotmail.com; Perry W Grigsby - pgrigsby@radonc.wustl.edu; Anurag K Singh* - singan@mail.nih.gov \\ * Corresponding author
}

Published: 05 May 2006

Radiation Oncology 2006, I:14 doi:10.1186/1748-7|7X-I-14

This article is available from: http://www.ro-journal.com/content/I/I//4

(C) 2006 Anders et al; licensee BioMed Central Ltd.

This is an Open Access article distributed under the terms of the Creative Commons Attribution License (http://creativecommons.org/licenses/by/2.0), which permits unrestricted use, distribution, and reproduction in any medium, provided the original work is properly cited.

\begin{abstract}
Background: The risk of severe cardiovascular toxicity, specifically thromboembolic events (TE), in patients with cervical cancer receiving concurrent irradiation and cisplatin chemotherapy is reported to be less than $1 \%$ in several large prospective trials. However, the anecdotal risk appears to be far higher.
\end{abstract}

Results and discussion: A review of several prospective trials demonstrates no treatment related grade 4 cardiovascular toxicities and only two grade 5 toxicities in $1424(0.1 \%)$ collective patients. A recent publication and our own unpublished experience finds 6 of $128(4.7 \%)$ patients developed grade 4 to 5 cardiovascular (thrombosis/embolism) toxicity. The differenc in incidence of severe or life threatening cardiovascular toxicity of 0.1 versus $4.7 \%$ is highly statistically significant $(\mathrm{p}<0.0000 \mathrm{I}$.)

Conclusion: This dramatic difference in incidence of cardiovascular toxicity raises the possibility that cardiovascular toxicities were inadequately reported on the listed prospective trials. For those patients enrolled in prospective trials, we suggest that thromboses should be diligently documented and reported. Only after the true incidence of thromboses is established can we implement appropriate levels of early screening and intervention that may prevent life threatening complications.

\section{Background}

A retrospective, case control study of 147 with carcinoma of the cervix or vagina treated with chemoradiotherapy with or without erythropoietin showed a 23 versus 3\% incidence of TE. [1] Such recent findings of an elevated risk of cardiovascular toxicity, specifically thromboembolic events (TE), in patients receiving concurrent irradiation, cisplatin chemotherapy and erythropoietin have spurred interest in the true incidence of TE in patients receiving concurrent irradiation and cisplatin chemotherapy in the absence of erythropoietin.

The use of cisplatin, either alone or in combination with other chemotherapeutic agents, has become the standard of care for the treatment of various solid tumors. Specifically, the routine use of cisplatin in the treatment of cancers of the uterine cervix has been cemented with the 
publication of several recent prospective randomized trials [2-8].

When reporting the results of these prospective trials, the scoring of treatment related toxicity is site specific. For example, TE are scored as cardiovascular toxicity and graded from 1 to 5 on the RTOG scale (Table 1). However, these trials often do not specify the incidence and severity of treatment related cardiovascular (thrombotic) toxicities. In fact, of the trials shown in Table 2, incidence of TE were only specifically reported in the study by Malfetano et al [4].

\section{Results and discussion}

A review of these prospective trials demonstrates no treatment related grade 4 cardiovascular toxicities and only two grade 5 toxicities (Table 2) in 1424 collective patients. According to the literature then, formation of severe or life threatening thromboses associated with cisplatin chemotherapy, in the absence of erythropoietin, is an exceedingly rare event.

The data in table 3, however, belies such rarity. A recent publication and our own unpublished experience yields (Table 3) 6 cases of grade 4 to 5 cardiovascular (thrombosis/embolism) toxicity in a cohort of 128 patients. The incidence of severe or life threatening cardiovascular toxicity in tables 2 and 3 was 0.1 versus $4.7 \%, \mathrm{p}<0.00001$.

Jacobson et al found a $16.7 \%$ incidence of TE 48 patients treated with definitive chemoradiation for cervical cancer. Four of these 48 patients developed grade 4-5 TE. [9] Of these 4 events, there were 3 grade 4 toxicities and 1 grade 5 toxicity. This is consistent with our unpublished institutional experience with 1 grade 4 and 1 grade 5 toxicity in a cohort of approximately 80 patients with pelvic malignancies treated with radiation and cisplatin chemotherapy, without erythropoietin.

The development of thromboembolic disease is dependent upon the relationship between the factors of Virchow's triad: stasis, hypercoagulability, and venous injury. As first described by Trouseau in the nineteenth century, and supported by modern publications, some patients with malignancy are hypercoagulable and do develop thromboses. [10,11] Simply from their malignancy, in the absence of chemotherapy, one might expect more than 2 reported cases of severe thrombotic events out of the 1424 patients described in Table 2.

In addition to the increase of thromboses as a result of malignancy, a review of chemotherapy associated vascular toxicity suggests that chemotherapeutic agents may increase the risk of thromboses by damaging vessel walls or producing changes in the clotting cascade [12]. Feffer et al. [13] reported that patients receiving chemotherapy for breast cancer showed a statistically significant reduction of functional protein $\mathrm{C}$ levels that returned to normal upon completion of therapy. Icli and associates [14] suggested that this severe vascular toxicity may be related to hypomagnesaemia, autonomic dysfunction, alteration in platelet aggregation, elevated plasma von Willebrand factor and hypercholesterolemia. Echoing these findings, several recent publications suggest that the incidence of venous thrombosis is further elevated in those patients receiving chemotherapy. [15-17]

Through vascular injury and possible alterations in the clotting cascade, chemotherapy agents such as cisplatin have the ability to affect coagulability and cause vascular injury, two aspects of Virchow's triad. Thus, though unsupported by the data from the trials summarized in Table 2, there is a theoretical basis to support the increased incidence of TE reported in table 3.

Venous stasis is well documented to cause thromboembolic events. The 6 events documented in Table 3 occurred in cervix cancer patients. It might be hypothesized that cervix cancer patients undergoing prolonged, in-patient brachytherapy procedures may be at a high risk for the development of DVT. Several retrospective studies of the perioperative morbidity and mortality of gynecologic brachytherapy have been performed [18-21]. These studies were performed in patients not receiving concurrent cisplatin chemotherapy and no excess risk of TE was described.

It remains possible that venous stasis during brachytherapy interacts with cisplatin to produce higher incidence of thromboembolic events. However, only 1 of the 4 grade

Table I: RTOG Cardiovascular (Thrombosis/Embolism) Toxicity Scoring

\begin{tabular}{ll}
\hline Grade & \\
\hline 1 & -------- \\
2 & DVT not requiring anticoagulation \\
3 & DVT requiring anticoagulation \\
4 & Pulmonary embolism from thromboses \\
5 & Death \\
\hline
\end{tabular}


Table 2: Incidence of thromboembolic toxicity in prospective studies using cisplatin

\begin{tabular}{|c|c|c|c|c|}
\hline Trial & Chemotherapy & XRT & Toxicity & No. CTX Pts \\
\hline Keys et al. [5] (cervix) & $\begin{array}{l}\text { Cis } 40 \mathrm{mg} / \mathrm{m}^{2} \mathrm{q} \mathrm{wk} \times 6 \\
\text { concurrent }\end{array}$ & 75 Gy to pt A & $\begin{array}{l}0 \text { deaths I Grade } 3 \& \mid \text { Grade } 4 \\
\text { CVT (NOS) }\end{array}$ & 183 \\
\hline Benedetti et al. [3] (cervix) & $\begin{array}{l}\text { Cis } 40-80 \mathrm{mg} / \mathrm{m}^{2} \mathrm{q} \text { wk } \times 6-8 \\
\text { concurrent }\end{array}$ & $\begin{array}{l}45-50 \text { Gy WP } 20-30 \text { Gy Low } \\
\text { Dose Rate }\end{array}$ & 0 deaths & 201 \\
\hline Morris et al. [2] (cervix) & $\begin{array}{l}\text { Cis } 75 \mathrm{mg} / \mathrm{m}^{2} \text { and } 5 \text {-FU } 4000 \\
\mathrm{mg} / \mathrm{m}^{2} \mathrm{q} \text { wk } \times 3 \text { concurrent }\end{array}$ & 85 Gy to pt A & I death (NOS) & 193 \\
\hline Pearcey et al. [6] (cervix) & $\begin{array}{l}\text { Cis } 40 \mathrm{mg} / \mathrm{m}^{2} \mathrm{q} \text { wk } \times 5 \\
\text { concurrent }\end{array}$ & 80 Gy to pt A & $\begin{array}{l}\text { I death (SBP) } 3 \text { Grade } 3 \text { CVT } \\
\text { (NOS) }\end{array}$ & 127 \\
\hline Peters et al. [7] (cervix) & $\begin{array}{l}\text { Cis } 70 \mathrm{mg} / \mathrm{m}^{2} \text { and } 5 \text {-FU } 1000 \\
\mathrm{mg} / \mathrm{m}^{2} \mathrm{q} \text { wk } \times 4 \text { concurrent }\end{array}$ & 4930 WP @ I70 cGy/day & $\begin{array}{l}\text { I death (Bilateral ureteral } \\
\text { obstruction) }\end{array}$ & 127 \\
\hline Rose et al. [8] (cervix) & $\begin{array}{l}\text { Cis } 40 \mathrm{mg} / \mathrm{m}^{2} \mathrm{q} \text { wk } \times 6 \\
\text { concurrent or Cis/5-FU/ } \\
\text { Hydroxyurea or Hydroxyurea }\end{array}$ & $80 \mathrm{~Gy}$ to pt $\mathrm{A}$ & $\begin{array}{l}0 \text { deaths } 2 \text { Grade } 3 \text { CVT } \\
\text { (NOS), with } 3 \text { drug regimen }\end{array}$ & 526 \\
\hline Malfetano et al. [4] (cervix) & Cis I mg/Kg q wk with XRT & $\begin{array}{l}45 \text { Gy PA, WP 4-5000 cGy and } \\
\text { 3-4000 cGy Low Dose Rate }\end{array}$ & 2 Grade 5 CVT (from PE) & 67 \\
\hline
\end{tabular}

NOS $=$ Not otherwise specified CVT $=$ Cardiovascular Toxicity SBP: Small Bowel Perforation Cis $=$ Cisplatin 5 FU $=5$ Fluorouracil WP $=$ Whole Pelvis Gy = Gray

4-5 TE described by Jacobson was associated with brachytherapy. Moreover, 6 of the 7 trials listed in Table 2 were performed in cervix cancer patients who underwent brachytherapy. Therefore, if the events in table 3 solely are due to venous stasis during brachytherapy interacting with cisplatin to produce higher incidence of thromboembolic events, then the similar patients from the randomized trials in Table 2 should have had a similar rather than a statistically significant difference $(\mathrm{p}<0.00001)$ in incidence of TE.

\section{Conclusion}

Combining the results of a recent publication and our own experience, we note 6 cases of grade 4 or 5 TE in patients receiving cisplatin and concurrent irradiation without erythropoietin for malignant disease including two deaths from thromboses (Table 3). Such an incidence is consistent with the known pro-thrombotic effects of malignancy and chemotherapy. However, data from prospective trials (Table 2) reported only 2 of 1424 having grade 4 or 5 TE. The dramatic difference in incidence of cardiovascular toxicity between Tables 2 and 3, raises the possibility that cardiovascular toxicities (specifically thrombosis, embolism) were inadequately reported on the listed prospective trials.
For those patients enrolled in prospective trials, we suggest that thromboses should be diligently documented and reported. Only after the true incidence of thromboses is established can we better evaluate the therapeutic ratio of cisplatin therapy with or without novel agents such as erythropoeitin. Also, this will allow the implementation of appropriate levels of early screening and intervention that may prevent life threatening complications.

\section{References}

I. Wun T, et al.: Increased incidence of symptomatic venous thrombosis in patients with cervical carcinoma treated with concurrent chemotherapy, radiation, and erythropoietin. Cancer 2003, 98(7): 15।4-20.

2. Morris M, et al:: Pelvic radiation with concurrent chemotherapy compared with pelvic and para-aortic radiation for highrisk cervical cancer. New England Journal of Medicine 1999, 340(I5): I I37-II43.

3. Benedetti-Panici $P$, et al:: Neoadjuvant chemotherapy and radical surgery versus exclusive radiotherapy in locally advanced squamous cell cervical cancer: results from the Italian multicenter randomized study. J Clin Oncol 2002, 20(I): 179-188.

4. Malfetano $\mathrm{JH}$, et al:: Extended field radiation andcisplatin for stage IIB and IIIB cervical carcinoma. Gynecol Oncol 1997, 67(2):203-207.

5. Rubin $P$, et al.: Systemic hemibody irradiation for overt and occult metastases. Cancer 1985, 55(9 Suppl):2210-21.

6. Pearcey $R$, et al.: Phase III trial comparing radical radiotherapy with and without cisplatin chemotherapy in patients with advanced squamous cell cancer of the cervix. J Clin Oncol 2002, 20(4):966-972.

Table 3: Incidence of thromboembolic toxicity in recent retrospective cohorts using cisplatin

\begin{tabular}{|c|c|c|c|c|}
\hline Trial & Chemotherapy & XRT & Toxicity & No. CTX Pts \\
\hline Jacobsen et al [9] (cervix) & Cis $40 \mathrm{mg} / \mathrm{m}^{2} \mathrm{q}$ wk $\times 6$ concurrent & 85 Gy to pt A & $\begin{array}{l}\text { I Grade } 5 \\
3 \text { Grade } 4 \text { CVT }\end{array}$ & 48 \\
\hline Mallincrodt (unpublished) (cervix) & Cis $40 \mathrm{mg} / \mathrm{m}^{2} \mathrm{q}$ wk $\times 6$ concurrent & $85 \mathrm{~Gy}$ to pt $\mathrm{A}$ & $\begin{array}{l}\text { I Grade } 5 \\
\text { I Grade } 4\end{array}$ & 80 \\
\hline
\end{tabular}

NOS $=$ Not otherwise specified CVT $=$ Cardiovascular Toxicity SBP: Small Bowel Perforation Cis $=$ Cisplatin $5 F U=5$ Fluorouracil WP $=$ Whole Pelvis Gy = Gray 
7. Peters WA, et al.: Concurrent chemotherapy and pelvic radiation therapy compared with pelvic radiation therapy alone as adjuvant therapy after radical surgery in high-risk earlystage cancer of the cervix. Journal of Clinical Oncology 2000, 18(8):1606-1613.

8. Rose PG, et al.: Concurrent cisplatin-based radiotherapy and chemotherapy for locally advanced cervical cancer. New England Journal of Medicine 1999, 340( I 5): I I 44- I I 53.

9. Jacobson GM, et al:: Thromboembolic events in patients treated with definitive chemotherapy and radiation therapy for invasive cervical cancer. Gynecol Oncol 2005, 96(2):470-4.

10. Trousseau A: Phlegmasia alba dolens Clinique Medicale de I'Hotel de Paris. London: New Sydenham Society; 1865.

11. Prandoni P, Piccioli A, Girolami A: Cancer and venous thromboembolism: an overview. Haematologica 1999, 84(5):437-45.

12. Weiss HA, Darby SC, Doll R: Cancer mortality following X-ray treatment for ankylosing spondylitis. Int J Cancer 1994, 59(3):327-38.

13. Weshler Z, et al.: Interstitial pneumonitis after total body irradiation: effect of partial lung shielding. $\mathrm{Br} J$ Haematol 1990, 74(1):6I-4.

14. Icli $F$, et al.: Severe vascular toxicity associated with cisplatinbased chemotherapy. Cancer 1993, 72(2):587-593.

15. Saphner T, Tormey DC, Gray R: Venous and arterial thrombosis in patients who received adjuvant therapy for breast cancer. J Clin Oncol I99I, 9(2):286-294.

16. Orlando L, et al.: Incidence of venous thromboembolism in breast cancer patients during chemotherapy with vinorelbine, cisplatin, 5-fluorouracil as continuous infusion (ViFuP regimen): is prophylaxis required? Ann Oncol 2000, II(I): II7-118.

17. Otten HM, et al: Symptomatic venous thromboembolism in cancer patients treated with chemotherapy: an underestimated phenomenon. Arch Intern Med 2004, I64(2): 190-4.

18. Dusenbery KE, Carson LF, Potish RA: Perioperative morbidity and mortality of gynecologic brachytherapy. Cancer 1991, 67(I I):2786-2790.

19. Lanciano $R$, et al.: Perioperative morbidity of intracavitary gynecologic brachytherapy. Int J Radiat Oncol Biol Phys 1994, 29(5):969-974.

20. Negrin RS, et al:: Transplantation of enriched and purged peripheral blood progenitor cells from a single apheresis product in patients with non-Hodgkin's lymphoma. Blood 1995, 85(II):3334-4I.

21. Jhingran A, Eifel PJ: Perioperative and postoperative complications of intracavitary radiation for FIGO stage I-III carcinoma of the cervix. Int J Radiat Oncol Biol Phys 2000, 46(5): I I77-I I 83.

\section{Publish with Biomed Central and every scientist can read your work free of charge}

"BioMed Central will be the most significant development for disseminating the results of biomedical research in our lifetime. "

Sir Paul Nurse, Cancer Research UK

Your research papers will be:

- available free of charge to the entire biomedical community

- peer reviewed and published immediately upon acceptance

- cited in PubMed and archived on PubMed Central

- yours - you keep the copyright

Submit your manuscript here:

http://www.biomedcentral.com/info/publishing_adv.asp
BiolMedcentral 